UDC 65.012 .4

https://doi.org/10.33619/2414-2948/48/30

JEL: H81, N90, 038, R53

\title{
DEVELOPING OF MANAGEMENT: CHOICE AND IMPLEMENTATION OF NEW TOOLS
}

\author{
CSolieva D., Andizhan Machine Building Institute, \\ Andizhan, Uzbekistan, soliyeva_dilnoza@mail.ru \\ (C)Teshabaev A., ORCID:0000-0001-6298-5018, SPIN-code: 5545-2892, Ph.D., \\ Fergana Polytechnic Institute, Fergana,Uzbekistan ateshabaev1958@gmail.com
}

\section{РАЗВИТИЕ УПРАВЛЕНИЯ: ВЫБОР И РЕАЛИЗАЦИЯ НОВЫХ ИНСТРУМЕНТОВ}

\section{(ССолиева Д. А., Андижанский машиностроительный институт, 2. Андижан, Узбекистан, soliyeva dilnoza@mail.ru}

(CTешабаев A. Э., ORCID: 0000-0001-6298-5018, SPIN-код: 5545-2892, Ph.D., Ферганский политехнический институт, г. Фергана, Узбекистан ateshabaev1958@gmail.com

Abstract. The research presented in this article shows the experience of implementing new Managerial tools in context of management and employees' development which is carried out in the large vehicle manufacturing company GM Uzbekistan. The paper describes the details of some new management techniques implementation and evaluated the results of implementation. Analysis of the results of innovation activity, questionnaire survey and special interview reveals of main influenced factors. Result of the research illustrates the importance of in-company culture and managerial style, empowerment and involvement of personnel, top management support and managerial stress, education and training programs. The management of the JVC General Motors Uzbekistan has actively tried to induce new managerial tools and techniques as Continuous Improvement activity through Employee's Suggestion System, Quality circle, 5S, TPM and others and MBO - Management by Objectives as tools for activation personnel potential and establishing self-managed teams within company employees. Within the framework of the visions of the Continuous Improvement a common understanding has developed, and the future direction of development has been negotiated. The history of Continuous Improvement in General Motors Uzbekistan demonstrates that success of new managerial techniques is not easy. The focus on the real problem areas, as quality, was, however, not a failure even though the targets were not met. The new managerial technology of human factor activating was later successfully utilized in the introduction of the focused Improvement team. The conclusion drawn from this is that management of company should, if possible, focus on collectivism aimed for real, vitally important areas and creative leaders.

Аннотация. Исследование, представленное в этой статье, показывает опыт внедрения новых управленческих инструментов в контексте управления и развития сотрудников, и проводится в крупной компании по производству транспортных средств «GM Uzbekistan». В статье описываются детали внедрения некоторых новых методов управления и оцениваются результаты внедрения. Анализ результатов инновационной деятельности, анкетирование и специальное интервью выявляют основные факторы влияния. Результат исследования иллюстрирует важность корпоративной культуры и стиля управления, расширения прав и возможностей и вовлечения персонала, поддержки высшего руководства и управленческого стресса, образовательных и обучающих программ. Руководство СП «Дженерал Моторс Узбекистан» активно пыталось внедрить новые управленческие инструменты и методы, 
такие как постоянное совершенствование, через систему предложений сотрудников, круг качества, 5S, ТРМ и другие, а также $\mathrm{MBO}$ - управление по целям в качестве инструментов для активизации кадрового потенциала и создание самоуправляемых команд внутри сотрудников компании. В рамках концепции непрерывного совершенствования сложилось общее понимание и были обсуждены будущие направления развития. История непрерывного совершенствования в General Motors Uzbekistan демонстрирует, что успех новых управленческих технологий не легок. Сосредоточение внимания на реальных проблемных областях, таких как качество, однако, не провал, хотя цели не были достигнуты. Новая управленческая технология активизации человеческого фактора впоследствии была успешно использована при внедрении целенаправленной команды по улучшению. Из этого следует вывод, что руководство компании должно, по возможности, сосредоточиться на коллективизме, ориентированном на реальные, жизненно важные сферы и творческих лидеров.

Keywords: management quality, development model, improvement team, managerial tools, innovation, quality circle, continuous improvement, auto industry, management by objectives, employee's suggestion system.

Ключевые слова: качество менеджмента, модель развития, команда по улучшению, управленческие инструменты, инновация, кружок качества, постоянное совершенствование, автоиндустрия, управление по целям, система предложений сотрудников.

\section{Introduction}

Globalization processes, i.e. increasing flow of goods and technologies puts pressure on companies to improve their efficiency in a continuous way $[1,8,9]$. Main part of effective company are modern management, there has been increasing awareness and implementation new Managerial tools and techniques in context of Continuous improvement (CI) or Kaizen in management of any companies. Especially ones need for manufacturing companies of the developing countries as Uzbekistan were just developed a new industrial branch as automotive production.

Continuous improvement often defined as a process of sustained incremental problem solving and company-wide innovative activity based on mass involvement, i.e. participation of main part of the workforce. Masaaki Imai (1986) summarized Kaizen as continuous improvement process involving everyone, managers and workers alike [10].

Many companies learnt that successful implementation of the Continuous Improvement tools as Employees Suggestion System (ESS), Quality Circle (QC) activity, Total Productive Maintenance (TPM) increased of productivity and efficiency, let to save lot of money, and improved of quality. Hyland et al. (2004) highlights the major potential benefits of CI as are both as increase business performance so increase "people performance" in the form of personal development [2]. This aspect of CI is very important for developing countries and countries with economy in transition. Verdinejad et al. (2010) demonstrate the application of the CI tool in simulation model of large Iranian holding development [13].

Companies' of Uzbekistan, which want become the industrial country and develops the new branches of industry as automotive manufacturing, also tried to implement new effective technique of CI.

Today productivity of Uzbek workers is considerably low by international standards, triggering the need to enable and motivate Uzbek workers to actively participate in development of production and increasing its effectiveness. In this regard, Powell (1999) states that implementation 
CI's methods and techniques is very important as form of Action learning and needs fundamental change in company's culture through people development [12].

There are some important reasons of that (on our opinion common for industrial companies of the every developing country):

Shortage of all kinds resources,

Low level of education and training of employees;

Lack of discipline and low morale of workers;

Low level of organizational culture and management skills [14-16].

As well as certain characteristics of workforce not encourage employees' involvement, initiative and empowerment. According to above mentioned, key issues for implementing CI in developing country's company is selection of the kinds of managerial techniques that are more effective in local culture's conditions.

\section{The Company development concept}

"GM-Uzbekistan" (Asaka, Uzbekistan) was a Joint-venture company, since 2007 forms part of USA-owned multi-national corporation General Motors and began independently operated as national automaker company in 2019. The company is now renamed to Joint Stock Company "Uzauto motors"[8, 9]

The company manufactures the several models of passenger cars and the micro-buses. The production site was opened in 1996 and was Uzbek-Korean owned Joint-Venture until the jointed to family GM. There are 7401 employees at this site with another 632 at the three other Uzbekistan sites.

After successful starting in 1996 by active supporting of the Uzbekistan government, the company experienced a severe recession in the early 2000s, when Korean partner - DAEWOO group was collapsed. However, an increase in orders, and production globalization from Korea to the Brazil, has led to a dramatic increase in output and recent return to profit $[4,9,10]$.

The company first embarked on Continuous Improvement in the 1998s, but this was regarded as having failed die, management believed, to a half-hearted approach.

A fresh attempt was made two years later, in 2000 which appears to have been more successful. The Continuous Improvement initiative has the support of the managers of all levels and, mainly from ISP - International Support Persons (1-st Deputy general director and him team of Korean specialists) after initial starting period, growing among the employees.

Thus, about twenty years ago, "Uz-DAEWOO Auto Co" (now Joint Stock Company "UZAUTO MOTORS") launched a large program focused on integrating the organization's Mission, Vision and Values into the work and culture of the organization. The program, led by the company's top management, was adopted because of the belief that strong innovative policy can lead to greater employee engagement and better organizational outcome. The management of the company made-out the following concept of company development (fig.1).

Under the Vision of company's future, the Mission was stressed that improving of quality of the Human resources and involvement through Paradigm changes should be used to create the Learning organization and climate of the Continuous Improvement. The Suggestion system, Education and Training, Quality circle, 5S' and TPM activity were selected as main tools for stirring up of employees.

Successful implementation of development model of the company greatly depends on consciousness of the personnel of the company. Only increasing the level of personnel consciousness, will it be possible to achieve targets set and utilize all opportunities available in developing company. It would be interesting to learn how this company aligns Quality of 
management to Human resources development through Continuous Improvement as the part of development strategy.

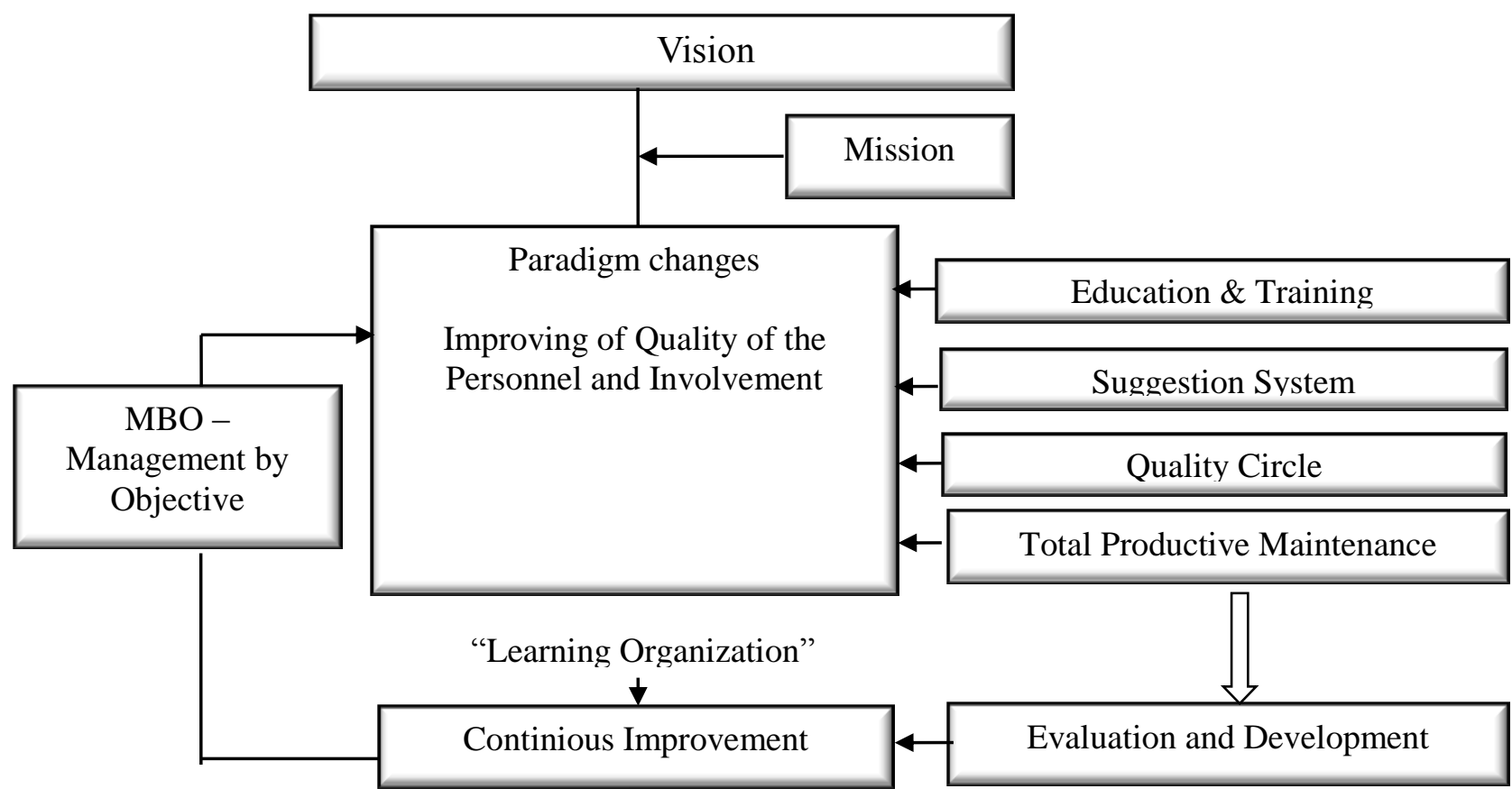

Figure 1: Concept of company' management development

\section{Implementation of innovation activity in the company}

The goal of program during the first years was simply Paradigms change awareness. All employees received four-hourly training on the company's organizational development concept and new managerial improvement techniques, and the training was incorporated into new employee and manager orientation.

A survey of employees following these trainings showed that the trainings were effective in increasing awareness of company's organizational development concept and developing new demands to workforce.

For developing the innovation activity and promotion of implementing a new techniques company management established special Cross-functional Innovation (Implementation) team included seven high-qualified and high-motivated specialists.

The Innovation team was educated and trained by company's top management and empowered for effective activity. As a result of this experimental phase it became clear that introducing any approach would require expert guidance and support, i.e. establishing special Innovation team.

The second of the program focused on engagement. The management (personally - 1st Deputy General Director from Korea) and Innovation team developed several tools for managers to increase the focus on Organizational development within their departments and to foster an environment in which the values would flourish.

Specifically, managers were instructed on how to establish goals for employees that align with the organization's using MBO - Management by objectives and to incorporate MBO method into the performance reviews.

The goal of the third phase of the program was adoption. Each month, the Innovation team developed events and programs that focused on a different core value of the organization and its divisions. For example, "OK rate" of production line as final determinants that shows effectiveness of production and quality. 
By this way company' Management through Innovation team activity arranged employee's activity and main goals of company. The program is constantly overseen by a company's top management and two positions were added to support the project. Progress of the program is tracked through a periodic, usually monthly reporting of every divisions of the company. Leaders of the company offered three recommendations for implementing the program at site:

Engage senior executives. Grassroots activities are important, but rolling them out and maintaining them organization-wide requires high-level support and inintiatives.

Coordinate timing so that the initiative does not conflict with other significant efforts.

Slow and steady wins the race. Incremental change brings small steps that lead to steady progress.

Below shows the list of managerial innovative techniques that was implemented in company (Table 1).

Table 1.

RESULTS OF ORGANIZATIONAL INNOVATIONS IN COMPANY

\begin{tabular}{|c|c|c|c|c|}
\hline Innovation & Period & Initiator & Mover/Driver & Result or status \\
\hline Suggestion System & 1998-1999 & $\begin{array}{l}\text { International support } \\
\text { person }\end{array}$ & Planning team & Undeveloped \\
\hline Quality circle & 1998-1999 & $\begin{array}{l}\text { International support } \\
\text { person }\end{array}$ & Planning team & Undeveloped \\
\hline $5 “ S ”$ & $2000-2009$ & $\begin{array}{l}\text { Management of } \\
\text { company }\end{array}$ & $\begin{array}{l}\text { Innovation } \\
\text { team }\end{array}$ & Routinized \\
\hline $\begin{array}{l}\text { MBO- Management by } \\
\text { objective }\end{array}$ & $2000-2008$ & $\begin{array}{l}\text { Management of } \\
\text { company }\end{array}$ & $\begin{array}{l}\text { Innovation } \\
\text { team }\end{array}$ & $\begin{array}{l}\text { Passing to GM- } \\
\text { GMS }\end{array}$ \\
\hline Suggestion system & 2000-present & $\begin{array}{l}\text { Management of } \\
\text { company }\end{array}$ & $\begin{array}{l}\text { Innovation } \\
\text { team }\end{array}$ & Developed actively \\
\hline Quality circle & 2001-present & $\begin{array}{l}\text { Management of } \\
\text { company }\end{array}$ & $\begin{array}{l}\text { Innovation } \\
\text { team }\end{array}$ & $\begin{array}{l}\text { Routinized } \\
\text { /Stagnation }\end{array}$ \\
\hline $\begin{array}{l}\text { TPM - Total Productive } \\
\text { Maintenance }\end{array}$ & $2002-2015$ & $\begin{array}{l}\text { Management of } \\
\text { company }\end{array}$ & $\begin{array}{l}\text { Innovation } \\
\text { team }\end{array}$ & Fading \\
\hline $\begin{array}{l}\text { Production system GM- } \\
\text { GMS }\end{array}$ & 2009-present & $\begin{array}{l}\text { Management of } \\
\text { company }\end{array}$ & GMS Team & Developed actively \\
\hline $\begin{array}{l}\text { Focusing Improvement } \\
\text { Team }\end{array}$ & 2012-present & $\begin{array}{l}\text { Management of } \\
\text { company }\end{array}$ & $\begin{array}{l}\text { Innovation } \\
\text { team }\end{array}$ & Actively developed \\
\hline
\end{tabular}

Lack of managerial support and mass enthusiasm were reasons of unsuccessful in the first trying to establish and develop Suggestion system and Quality circle in 1998-1999. These early attempts did not however bring their fruits as expected, but constituted learning process in planting suggestion system and small group activities in plant. Total productive management also has not developed through shortage of the mass enthusiasm of employees and special national character features, and it is fading to 2015.

The Employees Suggestion System and Quality circle activity as most developed managerial technique and as main Continuous Improvement tools was selected for more detail analysis.

\section{The Suggestion System}

Suggestion systems are important features of Continuous Improvement program everywhere. Many companies with developed suggestion systems have shown the importance of improvement in quality and quantity of production. There has been little empirical research on the issue of suggestions in companies of developing countries.

Origination and development of Samsung company's Suggestion System described by Kung (1999) [12]. Real experience on how a scheme of continuous improvement has been gradually 
transformed, from a very unsuccessful start, passing through different phases and finally delivering results for the firm is shown by Marin-Garsia et all (2007) [7].

While there have been studies about modern production systems, there has been little specific focus on suggestion systems in aspects of employees development. For this reason, we conducted research on the "human side" of suggestion system in company that established a well-organized suggestion system. Research has found that Employees Suggestion System is a useful way to obtain and utilize employee's creative ideas. To be effective, employees must be motivated to participate in the Suggestion system.

The Suggestion System operated by the General Motors Uzbekistan (now Joint Stock Company "UZAUTO MOTORS") generated over 90 thousand suggestions for improving manufacturing processes over a span of 10 years, including suggestions both of individuals - as each employee Ideas and of Quality circles - as group decision making. The average number of suggestions submitted by each employee per year is 2.1 , that approximately similar as 10 years ago for Britain companies [11]. The saving from suggestions in the company in this period was approximately 3.9 billion Uzbek sums (approximately US\$2.530.000).

The Table 2 shows the resulting performance of system at the company.

Table 2 .

SUGGESTION SYSTEM DEVELOPMENT STAGES

\begin{tabular}{lllll}
\hline \multicolumn{1}{c}{ Contents } & \multicolumn{1}{c}{$\begin{array}{c}\text { Introduction } \\
(1998 \sim 2001)\end{array}$} & $\begin{array}{c}\text { Diffusion } \\
(2001 \sim 2006)\end{array}$ & $\begin{array}{c}\text { Activation } \\
(2007-2012)\end{array}$ & $\begin{array}{c}\text { Quality seeking } \\
(2013 \sim \text { present })\end{array}$ \\
\hline Suggestion per person & 0.03 & 1.1 & 2.0 & 2.1 \\
Implementation rate, \% & 52.2 & 16.4 & 41.4 & 66.9 \\
Involvement Rate, \% & 5.8 & 48.4 & 60.2 & 82.7 \\
\hline
\end{tabular}

As shown in the Table 2, four stages were identified:

1) introduction,

2) diffusion,

3) activation and

4) quality-seeking stages.

The average number of suggestion increased to 11486 in Activation stage and dropped to 11172 Quality seeking stage, because the evaluation level for adoption was raised. Regardless, the average number of suggestions per person rather went up.

In view of the $66.9 \%$ implementation of the adopted suggestions which is compared with $41.4 \%$ in the previous stage, and $82.7 \%$ involvement which is compared with $60.2 \%$ in the previous stage. This indicates the company began to enter the qualitative approach from the quantitative one's.

The characteristics of each stage in the development of suggestion system are shown in the following figure.

As shown in Table 3 the company firstly introduced the suggestion system in 1998. Then system was widely disseminated during the period of 2001 2006.

During the 2007 2012, the system was activated owing to the increasing number of suggestions throughout the factory.

In the 2013, there are enter quality-seeking phase, focus of ESS changed from quantitative to qualitative approach, with the purpose of meeting the corporate concept of development.

\section{Individual and Group Innovative activity}

People at all levels of the company participate in Continuous improvement (Kaizen), from the directors down to shop-floor staff. The format for CI activity can be individual — suggestion 
system or collective - in the small groups. Various tools are used to allow workers to be involved in a collective improvement process - Quality Circle (QC), Focused Improvement Team (FIT), Cross-functional Problem-solving team (CFPST) and Temporary Aggregate Working Group (TAWG).

Individual suggestion making is most developed method of the mass innovative activity. More than $82 \%$ of all employees participate in Suggestion activity and they made out more than 12000 ideas in 2010 .

Table 3.

MAIN CHARACTERISTICS OF SUGGESTION SYSTEM DEVELOPMENT STAGES

\begin{tabular}{|c|c|}
\hline Stage & Characteristics \\
\hline $\begin{array}{l}\text { Introduction } \\
(1998 \sim 2001)\end{array}$ & $\begin{array}{l}\text { establishing the Education center of company; } \\
\text { training on real-life examples for middle-range and front-line managers; } \\
\text { introduction of Suggestion System basically. }\end{array}$ \\
\hline $\begin{array}{l}\text { Diffusion } \\
\text { (2001 2006) }\end{array}$ & $\begin{array}{l}\text { establishment of rewarding system for implementation; } \\
\text { establishment of Suggestion Secretariat and Award Committee; } \\
\text { started Quality Circle conferences. }\end{array}$ \\
\hline $\begin{array}{l}\text { Activation } \\
(2007-2012)\end{array}$ & $\begin{array}{l}\text { active implementation of Suggestion System; } \\
\text { computerization of Suggestion System management. }\end{array}$ \\
\hline $\begin{array}{l}\text { Quality seeking } \\
\text { (2013 present) }\end{array}$ & $\begin{array}{l}\text { developing new form of group decision making - Quality Improvement Team; } \\
\text { standardization of evaluation processes; } \\
\text { publication of manual for evaluation and rewards on implementation; } \\
\text { expansion of suggestion system to suppliers; } \\
\text { development the Suggestion System. }\end{array}$ \\
\hline
\end{tabular}

Company also uses groups to make innovations for several reasons. First is group is more effective both as productive aspect so employees development aspects because synergy, which occurs when group members find the decision making to problems through the process of mutual influence within the group. Another reason for using a group is to gain commitment to a decision, and Quality circles are empowered to implement their own decision-making and recommendations.

The Quality circle activity in company flourished during 2000s and in 2008 number of QC was 200 with 1259 members. During all this years' company conduct 13 annual conference of Quality circles. Analysis of the participant lists of these conferences shown that only 26 Quality circles headed by creative and ambitioned leaders participated in conferences twice and more times. Only 9 Quality circles was winners of these conferences, i.e. really active and effective Quality circle's number is few.

It has been estimated that 40 to 65 percent of Quality circle have failed in first 3 years or not developed. Reasons for failures have included a low level of education and lack of problem-solving skills among Quality circles members. But, as experience shown, main reason is low motivation of QC members, because its activity is voluntary overtime works.

Focused improvement team, started in March, 2011 as Quality Improvement Teams, as contrast, are included in the improvement efforts as part of a change in the organization' structure through empowerment of line's working team for Quality improvement. Improvement teams are generated from top down and empowered to act on their demands. The decision-making activities of QITs are narrower focused than those of quality circle. The results of individual and group innovative activity are shown below in Table 3.

Analysis of the Suggestion system results in 2001-2008 years (rate of involvement 18,4 $49,1 \%$ and rate of implementation $62.3 \sim 35.9 \%$ ) shown limited usage of applied managerial tools to manage of innovation activity for implementation of innovation into practices of company. 
Instability of performance shown absent of the regular trend of innovative activity, i.e. innovative processes are not controllable.

Table 4.

MAIN RESULTS OF INNOVATION ACTIVITY

\begin{tabular}{|c|c|c|c|c|c|c|c|c|c|c|}
\hline & & $\begin{array}{c}200 \\
1\end{array}$ & 2002 & 2005 & 2007 & 2009 & 2011 & 2013 & 2015 & $\begin{array}{c}2017 \\
*\end{array}$ \\
\hline \multirow{4}{*}{$\begin{array}{l}\text { Employees } \\
\text { Suggestion } \\
\text { System }\end{array}$} & No of suggestors, ea & 644 & 1775 & 1898 & 1987 & 2289 & 4740 & 4751 & 5294 & 5324 \\
\hline & $\begin{array}{l}\text { Suggestion per } \\
\text { person, ea }\end{array}$ & $\begin{array}{l}2.3 \\
6\end{array}$ & 1.56 & 1.63 & 1.99 & 1.41 & 1.9 & 1.95 & 2.11 & 2.1 \\
\hline & $\begin{array}{l}\text { Implementation rate, } \\
\%\end{array}$ & $\begin{array}{l}62 . \\
3\end{array}$ & 55.2 & 57.3 & 55.1 & 35.9 & 37.2 & 40.1 & 43.4 & 42.3 \\
\hline & $\begin{array}{l}\text { Involvoment of } \\
\text { Employees, \% }\end{array}$ & $\begin{array}{l}18 . \\
4\end{array}$ & 51.7 & 57.3 & 61.1 & 49.1 & 67.8 & 75.6 & 75.6 & 76.0 \\
\hline \multirow{4}{*}{$\begin{array}{l}\text { Quality } \\
\text { circles** }\end{array}$} & $\begin{array}{l}\text { No of Quality circles, } \\
\text { ea }\end{array}$ & 13 & 54 & 132 & 143 & 18 & 67 & 88 & 93 & 66 \\
\hline & $\begin{array}{l}\text { Suggestion per QC, } \\
\text { ea }\end{array}$ & 2.3 & 4.2 & 3.1 & 3.8 & 3.9 & 4.2 & 4.3 & 2.6 & 0.5 \\
\hline & Member of QC,ea & 80 & 403 & 887 & 973 & 125 & 169 & 829 & 912 & 598 \\
\hline & $\begin{array}{l}\text { Involvoment of } \\
\text { Employees, \% }\end{array}$ & $\begin{array}{l}2,3 \\
1\end{array}$ & 11,7 & 26,8 & 29,9 & 1.82 & 11,7 & 11,8 & 13.0 & 8.54 \\
\hline
\end{tabular}

* on base of Data for 2018.11.11

** Quality circles activity in 2009 was interrupted by organizational reasons

Quality circles performances also had shown instability - limited growth of their number (from 13 ea QC in first 2001 to 143 ea. in 2007) but one-yearly interruption almost collapsed Quality circles system. Only 14,5\% of QC (29 ea of 200) has sufficient positive results and participated in annual QC conferences twice or more times.

Involvement employees in QC activity never exceed the $29,9 \%$ and according to our estimation about $80 \%$ of them was not active participant. Reason for that is next.

A Quality circle itself is a completely voluntary body. There are management no forced and paid for join, no penalized for absent of result. The motivation is solely the desire to do a constructive job of work. But decision and recommendations of Quali circles often were a very effective and always useful on practice.

Focused Improvement team activity started in March 2011, but shows a very impressive results. Started by initiative and support of company's top management this form of group decisionmaking is most effective and fast grown.

According top management guidance Improvement team activity is focusing on product quality and in period 9 month there are recorded the establishing 114 improvement team with 893 members and high productivity of them - 827 Improvement team suggestions, i.e. it means 7,25 suggestions per Quality improvement team in 8 month of activity.

Quality Improvement teams based on production units, usially on one workstation, and developed its own work area's quality problems with target one quality problem must be eliminate in one month (in ideal case). There are special recording and reporting system on implemented ideas on improvement. Every shop must orginize on working places special presentations of results QIT. Developed awarding system, strong managerial attention and control, and on our opinion strong managerial stress for improving product and processes quality within QIT activity, are source of active development QIT and its effectiviness.

The generally results show that the company improved its innovation productivity by around 200 per cent between 2002 and 2009. But employees involvement rate increase only 159 per cent 
and implementation rate increase only 114 per cent. Employees involvement highest index for individual innovations was $82,7 \%$ and for group innovations was $19,9 \%$.

\section{Empowerment Practices in Action}

Company top management strong supports of Continuous Improvement activity. In the beginning phase the company has the Innovation team include 7-9 permanent paid high qualified best employees as facilitators. These facilitators oversee about 12000 improvement events per year within the organization.

Front-line managers and person-in charge for Suggestion activity work together on the Innovation team, which helps to provide suggestion making activity within the different departments.

Front-line managers was to find as person-in charge for Suggestion activity to be empowering because they serve as a driver for expressing ideas, writing Improvement suggestions and implementing change. Through the suggestion making process, the teams develop production boards that they then post on the walls.

Every year about two thousands employees received additional training on Suggestion activity. The company management reviews monthly reports on Suggestion activity progress. Survey of employee engagement at company shows that employees who are involved in suggestionmaking activity (approximately 82,7\%) are more engaged than those who have not participated $(17,3 \%)$. The company estimates that it has saved over 46178 millions soums (approximately 2,530 thousands USD) through improvements resulting from applications of suggestion system since the inception of the program.

\section{Effective Factors of Suggestion System}

One of the aims of this paper was investigating effective factors in operating Continuous Improvement at the company. In order to conduct the research, an experience of the company was excavated in search of its characteristics in the suggestion system. Further, a questionnaire survey was conducted from 144 workers (best suggestion-makers, person in charge for suggestions, team members, etc.) in order to investigate what they think about the system and problems of system.

Relevant data was obtained and then analyzed for study (Table 5).

Main findings are the next.

Suggestion system activity is result firstly of managerial stress, secondly of busting the job demands.

Motivation through new paradigms movement is ineffective.

Group suggestions is not much more effective than individual.

Suggestion system must be developed through improving the speed of evaluation and by using more simple procedure of evaluation.

For better motivating of suggestion-makers rewarding amount of money must be extend.

Some other quantitative finding by special interviews with best suggestion-maker workers includes following.

Just $40 \%$ of employees think their senior management really support new ideas and new ways of doing things.

Just $36 \%$ of employees think senior management tries to be visible and accessible to employees.

A $42 \%$ of employees think company's employee suggestion system is ineffective. 
RESULTS OF CI FACTORS ESTIMATION

Table 5 .

\begin{tabular}{|c|c|c|c|c|c|c|c|c|}
\hline $\begin{array}{l}\text { Factors affecting on innovation } \\
\text { activity }\end{array}$ & 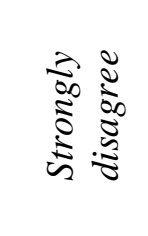 & 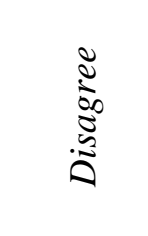 & $\underset{\mathbb{Z}}{\stackrel{\Xi}{*}}$ & $\frac{\mathscr{2}}{\infty}$ & 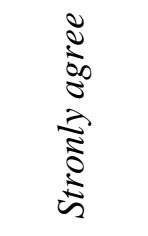 & $\underset{\sqrt[3]{0}}{2}$ & 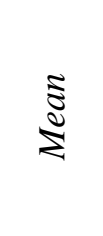 & 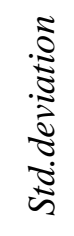 \\
\hline $\begin{array}{l}\text { Suggestions are result of the } \\
\text { busting the job demands }\end{array}$ & $6(4,2)$ & $21(14,6)$ & $55(38,2)$ & $21(14,6)$ & $14(9,7)$ & 144 & 3,465 & 1,17 \\
\hline $\begin{array}{l}\text { Suggestions are result of } \\
\text { managerial stress }\end{array}$ & $4(2,7)$ & $10(6,9)$ & $28(19,4)$ & $41(28,4)$ & $61(42,1)$ & 144 & 3,965 & 1,09 \\
\hline $\begin{array}{l}\text { Suggestions are result of } \\
\text { employee involvement and } \\
\text { development }\end{array}$ & $16(11,1)$ & $15(10,4)$ & $53(36,8)$ & $38(26,3)$ & $22(15,3)$ & 144 & 3,257 & 1,18 \\
\hline $\begin{array}{l}\text { Suggestions are result of } \\
\text { "Shijoat" movement }\end{array}$ & $2(1,3)$ & $69(47,9)$ & $47(32,6)$ & $20(13,9)$ & $6(4,2)$ & 144 & 2,729 & 0,89 \\
\hline $\begin{array}{l}\text { Lack of support of front-line } \\
\text { managers and innovation team }\end{array}$ & $13(9,0)$ & $19(13,2)$ & $52(36,1)$ & $28(19,4)$ & $32(22,2)$ & 144 & 3,326 & 1,21 \\
\hline $\begin{array}{l}\text { Importance of training and } \\
\text { education for suggestion-making } \\
\text { development }\end{array}$ & $8(5,5)$ & $13(9,2)$ & $31(21,5)$ & $49(34,0)$ & $43(29,8)$ & 144 & 3,736 & 1,14 \\
\hline $\begin{array}{l}\text { Group suggestions are more } \\
\text { effective than individual }\end{array}$ & $26(18,0)$ & $33(22,9)$ & $41(28,4)$ & $17(11,8)$ & $27(18,8)$ & 144 & 2,902 & 1,35 \\
\hline $\begin{array}{l}\text { Speed of evaluation and } \\
\text { rewarding is good }\end{array}$ & $31(8,3)$ & $41(28,4)$ & $37(25,6)$ & $26(18,0)$ & $9(6,2)$ & 144 & 2,590 & 1,19 \\
\hline $\begin{array}{l}\text { Procedure of evaluation is simple } \\
\text { and convenient }\end{array}$ & $29(20,1)$ & $44(30,5)$ & $25(17,3)$ & $31(21,5)$ & $15(10,4)$ & 144 & 2,715 & 1,29 \\
\hline $\begin{array}{l}\text { Rewarding amount is not enough } \\
\text { to motivate suggestion-making }\end{array}$ & $8(5,6)$ & $28(19,4)$ & $21(14,6)$ & $28(19,4)$ & $61(42,3)$ & 144 & 3,708 & 1,32 \\
\hline
\end{tabular}

* Note: The parenthesized values indicate percentage.

\section{Strong support of top management}

Top management strongly and visibly supports the development of the suggestion system. Until last year, to solicit a suggestion from employees, any reasonable suggestion had been welcome so that data could be accumulated in a large quantity. The goal was to develop employee's capabilities to create new idea, to generate ability to make suggestions through receiving a new knowledge and skills. As a most of employees has received experience of suggestion-making, quantitative approach was encouraged by top management and factory turned to qualitative approach in 2010-2012.

Top management, as a main driving force, urges employees to participate in the training program and contributed to the integration of the Suggestion system through rewarding system and feedback.

\section{Involvement and personal development}

On employee's viewpoint, suggestion making itself is important part of his worklife and important for company activity. Also, employees who feel a high level of accomplishment from the job would more suggestions and involvement is an important input to make a suggestion. 


\section{Participation}

As mentioned previously, employees have extensively been involved in the suggestion process and successful suggestion system is a result of employee involvement practices. This company actively supports employee involvement, with a participation rate of $82.7 \%$ of total workers so that can reap organizational creativity. Subordinates are strongly encouraged to learn how to make suggestions by individual and group. An atmosphere of participation encouraged regarding a suggestion.

\section{Evaluation procedure}

The Suggestion system in company has been developed in a manner that employees actively participated in suggestion implementation and can see the current status of the submitted suggestion. The procedure of evaluation is simple, speedy and convenient to participants. The results of final decision are quickly disclosed regarding implementation. Although employees seem to have some monetary reward, they are quite satisfied with the evaluation procedure.

The generalization of the above mentioned opinions of employees about Suggestion system and its acted factors for personnel indicates in the Figure 2.

Thus, based on results of this study, we can say - for Quality of management in context improving the company outer performance may be rise by implementing of new managerial tools both as Continuous improvement and as Personnel development tool. Effective implementation of these personnel-based possible in the next conditions:

messages to personal regarding who is invited to participate must be clear (in principle - all employees);

education and training are very important in the first phase of system development;

rewarding procedure must be suitable and clear for all employees; especially for engineers and operators

Continuous improvement needs in continuous support for system.

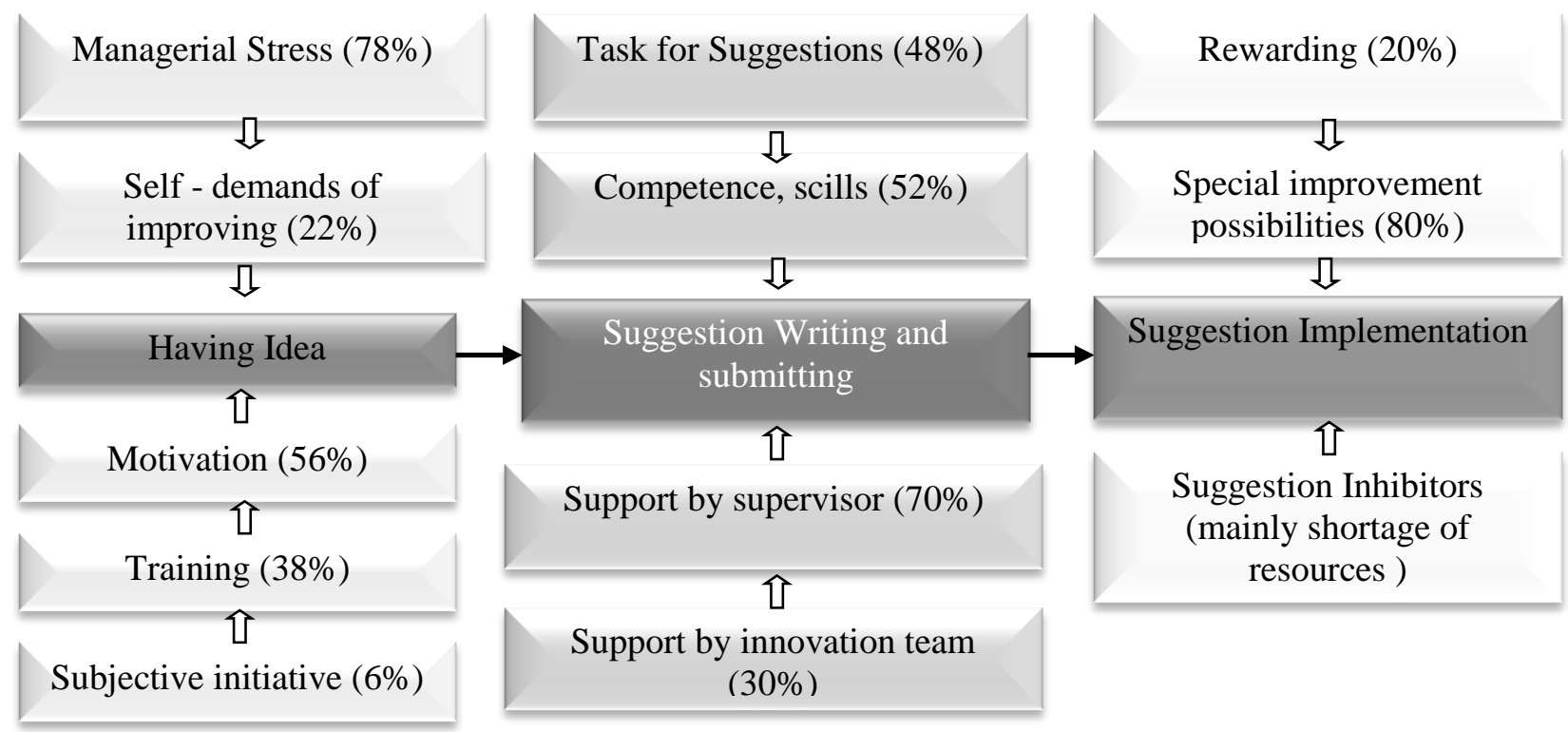

Figure 2. Structure of suggestion system factors

\section{Conclusion}

The management of the Joint Stock Company "UZAUTO MOTORS" has actively tried to induce new managerial tools and techniques as Continuous Improvement activity through Employee's Suggestion System, Quality circle, 5S, TPM and others and MBO - Management by Objectives as tools for activation personnel potential and establishing self-managed teams within 
company employees. Within the framework of the visions of the Continuous Improvement a common understanding has developed and the future direction of development has been negotiated.

The role of the management has been that of a driver and conductor in the Continuous Improvement process. This strategy has enabled the management to influence the development of employees with relatively limited resources.

The development of Continuous Improvement tools as Employees Suggestion System and role played by the decision-making groups as Quality circles and Improvement teams indicates that managerial support, including training and employees' development program are important.

In our current conditions managerial stress is main motivator and driver of changes. In this process, employee's development has been equally important for the Continuous Improvement.

The history of Continuous Improvement in Joint Stock Company "UZAUTO MOTORS" demonstrates that success of new managerial techniques is not easy. The focus on the real problem areas, as quality, was, however, not a failure even though the targets were not met.

The new managerial technology of human factor activating was later successfully utilized in the introduction of the focused Improvement team. The conclusion drawn from this is that management of company should, if possible, focus on collectivism aimed for real, vitally important areas and creative leaders [4-6].

This experience also shows that well established Suggestion systems must be developed on basis of local living standards and national culture styles. Given the right environment and sensible managerial policy, it is possible to sharply developed Innovation activity in desired direction and to increase its efficiency.

\section{Facilitating the Adoption of Continuous Improvement Tools}

Findings from this experience and the literature review suggest that there are several actions that can facilitate the adoption of new managerial tools for improving of the Quality of management. We offer the following recommendations for the adoption of new tools of activating personnel potential:

Commit to an organizational culture that focuses on quality and productivity. Use organizational culture for support that new tools and techniques.

Engage leadership support. Ensure that top and middle level managers are involved in the implementation and developing of new managerial techniques and that they reinforce the importance of these tools for employees.

Involve the employees in strategic planning. Ensure that employees understand and sharing the Vision, Mission, Purpose and Goals of company.

Identify challenges and opportunities for employees learning and development. Make sure your company has a critical mass of professionals who have the training and experience to understand, implement, and evaluate these best practices.

\section{Reference:}

1. Abdullaev, A. M., \& Kurpyanidi, K. I. (2018). To the Problem of Classification of Institutional conditions determining enterprise structure in Uzbekistan. Scientific-technical journal, 22(1), 101-106. https://uzjournals.edu.uz/ferpi/vol22/iss1/11

2. Hyland, P. W., Milia, L. D., \& Terry, R. S. (2004). CI Tools and Technique: Are there any difference between firms. In Proceedings 5th CINet Conference, Sydney, Australia. http://handle.uws.edu.au:8081/1959.7/44677

3. Kang, B. S. (1998). An Effective suggestion System under tpm: an Experience of Samsung corning, inc in Korea. In Proceedings of the Korean Society for Quality Management Conference (51-60). The Korean Society for Quality Management. 
4. Kurpayanidi, K. I., \& Abdullaev, A. M. (2018). Activation of foreign economic relations on the basis of innovative development. Practice of Uzbekistan/LAP LAMBERT Academic Publishing, European Union, Germany.

5. Kurpayanidi, K. I., \& Abdullaev, A. M. (2018). Actual issues of the functioning of an innovative industrial enterprise. ISJ Theoretical \& Applied Science, 11(67), 74-81.

6. Kurpayanidi, K. I. (2018). Questions of classification of institutional conditions, determining the structure of business management in Uzbekistan. ISJ Theoretical \& Applied Science, 9(65), 1-8.

7. Marin-Garcia, J. A., \& Miralles, C. (2007). Group versus individual suggestions systems: a longitudinal case study. In 19th International Conference on Production Research.

8. Margianti, E. S., Ikramov, M. A., Abdullaev, A. M., Kurpayanidi, K. I., \& Ashurov, M. S. (2014). Systematical analysis of the position and further development of Uzbekistan national industry in the case of economic modernization. Monograph. Indonesia, Jakarta. Indonesia. Jakarta. Gunadarma Publisher.

9. Margianti, E. S. (2016). ets. Entrepreneurship in Uzbekistan: trends, competitiveness, efficiency. Indonesia, Jakarta, Gunadarma Publisher.

10. Masaaki, I. (1986). Kaizen: The key to Japan's competitive success. New York, ltd: McGraw-Hill.

11. Oliver, N., Delbridge, R., \& Barton, H. (2002). Lean production and manufacturing performance improvement in Japan, the US and UK 1994-2001. http://www.cbr.cam.ac.uk/pdf/WP232.pdf

12. Powel, J. A. (1999). Action learning for continuous improvement and enhanced innovation in construction. Proceedings of IGLC-7, 433-444.

13. Verdinejad, F., Mokhtari Mughari, A., \& Ghasemi, M. (2010). Organizational suggestion system in the era of holding by developing an innovative model: the case of bonyade ta avon holding in Iran (an applied model). Iranian Journal of Management Studies, 3(3), 5-22. https://dx.doi.org/10.22059/ijms.2011.21798

14. Teshabaev, A. E. (2018). The Methodological approaches to Management improving for modern Companies. Scientific-technical journal, 22(2), 108-115. https://uzjournals.edu.uz/ferpi/vol22/iss2/30

15. Teshabaev A. E. (2017) The Improvement the Management of Modern companies. Tashkent.

16. Teshabaev, A. E., Useinov, S. E., Ametov, V. A., \& Leont'ev, K. M. (2006). Problemy i modeli vnedreniya novykh upravlencheskikh tekhnologii. Vestnik Tomskogo gosudarstvennogo arkhitekturno-stroitel'nogo universiteta, (2), 167-176.

\section{Список литературы:}

1. Abdullaev A. M., Kurpyanidi K. I. To the Problem of Classification of Institutional conditions determining enterprise structure in Uzbekistan // Scientific-technical journal. 2018. V. 22. №1. P. 101-106. https://uzjournals.edu.uz/ferpi/vol22/iss1/11

2. Hyland P. W., Milia L. D., Terry R. S. CI Tools and Technique: Are there any difference between firms // Proceedings 5th CINet Conference, Sydney, Australia. 2004. http://handle.uws.edu.au:8081/1959.7/44677

3. Kang B. S. An Effective suggestion System under tpm: an Experience of Samsung corning, inc in Korea // Proceedings of the Korean Society for Quality Management Conference. The Korean Society for Quality Management, 1998. P. 51-60.. 
4. Kurpayanidi K. I., Abdullaev A. M. Activation of foreign economic relations on the basis of innovative development // Practice of Uzbekistan/LAP LAMBERT Academic Publishing, European Union, Germany. 2018.

5. Kurpayanidi K. I., Abdullaev A. M. Actual issues of the functioning of an innovative industrial enterprise // ISJ Theoretical \& Applied Science. 2018. V. 11. №67. P. 74-81.

6. Kurpayanidi K. I. Questions of classification of institutional conditions, determining the structure of business management in Uzbekistan // ISJ Theoretical \& Applied Science. 2018. V. 9. №65. P. 1-8.

7. Marin-Garcia J. A., Miralles C. Group versus individual suggestions systems: a longitudinal case study // 19th International Conference on Production Research. 2007.

8. Margianti E. S., Ikramov M. A., Abdullaev A. M., Kurpayanidi K. I., Ashurov M. S. Systematical analysis of the position and further development of Uzbekistan national industry in the case of economic modernization. Monograph. Indonesia, Jakarta // Indonesia. Jakarta. Gunadarma Publisher. 2014.

9. Margianti E. S. Entrepreneurship in Uzbekistan: trends, competitiveness, efficiency // Indonesia, Jakarta, Gunadarma Publisher. 2016.

10. Masaaki I. Kaizen: The key to Japan's competitive success // New York, ltd: McGraw-Hill. 1986.

11. Oliver N., Delbridge R., Barton H. Lean production and manufacturing performance improvement in Japan, the US and UK 1994-2001. 2002. http://www.cbr.cam.ac.uk/pdf/WP232.pdf

12. Powel J. A. Action learning for continuous improvement and enhanced innovation in construction // Proceedings of IGLC-7. 1999. P. 433-444.

13. Verdinejad F., Mokhtari Mughari A., Ghasemi M. Organizational suggestion system in the era of holding by developing an innovative model: the case of bonyade ta avon holding in Iran (an applied model) // Iranian Journal of Management Studies. 2010. V. 3. №3. P. 5-22. https://dx.doi.org/10.22059/ijms.2011.21798

14. Teshabaev A. E. The methodological approaches to management improving for modern companies // Scientific-technical journal. 2018. V. 22. №2. P. 108-115. https://uzjournals.edu.uz/ferpi/vol22/iss2/30

15. Тешабаев А. Э. Совершенствование управления на современных предприятиях. Т., 2017,232 c.

16. Тешабаев А. Э., Усеинов С. Э., Аметов В. А., Леонтьев К. М. Проблемы и модели внедрения новых управленческих технологий // Вестник ТГАСУ. 2006. №2. С. 167-176

Работа поступила

в редакиию 14.10.2019 2.
Принята к публикацุии 19.10.2019 2.

\section{Ссылка для иитирования:}

Solieva D., Teshabaev A. Developing of Management: Choice and Implementation of New Tools // Бюллетень науки и практики. 2019. Т. 5. №11. С. 262-275. https://doi.org/10.33619/2414-2948/48/30

Cite as (APA):

Solieva, D., \& Teshabaev, A. (2019). Choice and Implementation of New Tools. Bulletin of Science and Practice, 5(11), 262-275. https://doi.org/10.33619/2414-2948/48/30 (in Russian). 